\title{
Descortinando a homofobia
}

\section{Homofobia: história e crítica de um preconceito.}

BORRILLO, Daniel.

Belo Horizonte: Autêntica Editora, 2010. $141 \mathrm{p}$.

Originalmente editado em francês, o livro Homofobia: história e crítica de um preconceito, de autoria de Daniel Borrillo, traz uma abordagem histórica, conceitual e crítica dessa forma de violência que, como demonstra a obra, é um fenômeno complexo e variado. Organizada em quatro capítulos, a versão brasileira recebeu prefácio de Marco Aurélio Máximo Prado, que pontuou a relevância da obra para o contexto nacional e a classificou como um clássico para o campo. Logo na introdução, - autor apresenta as principais ideias a serem discutidas e problematiza o conceito de homofobia, esclarecendo que muitos dos olhares sobre esse tipo de violência são limitados e passíveis de aprofundamento. Borrillo explica que as origens da violência homofóbica estão fixadas junto às da civilização judaico-cristã e que, por isso, as citações históricas e referências teóricas contidas na obra são incompletas e não visam esgotar a discussão em torno do tema.

No primeiro capítulo, a violência homofóbica é didaticamente classificada e conceituada, definindo-se homofobia como uma forma de inferiorizar, desumanizar, diferenciar e distanciar o indivíduo homossexual à semelhança de outras formas de exclusão como a xenofobia, o racismo, o antissemitismo ou o sexismo. É nesse momento que Borrillo sublinha a complexidade do fenômeno e o descreve como invisível, cotidiano, compartilhado e que, ao mesmo tempo que transforma o homossexual naquele com quem não se deve identificar e que não deve ter plenos direitos, gera também ônus aos heterossexuais ao aliená-los. Neste capítulo, Borrillo demonstra que a homofobia baliza, além das fronteiras sexuais, as de gênero, fazendo com que todos os indivíduos não pertencentes à ordem clássica dos gêneros sejam vitimados pela violência homofóbica. $O$ autor amplia o conceito de homofobia ao problematizar que essa violência funda-se, especialmente, na rígida hierarquia que situa outras formas de vivência da sexualidade em lugares inferiores ao destinado à heterossexualidade.

O segundo capítulo apresenta as origens da homofobia e discute a transição da relativa tolerância, vivenciada na cultura pagã, para a hostilidade, exercida pelo cristianismo, às relações homossexuais. O autor, oportunamente, pontua que a Igreja Católica contemporânea apresenta um tom mais sutil ao acolher os homossexuais para curá-los ou, minimamente, mantê-los abstinentes. No terceiro capítulo, a homofobia é descrita como uma forma de violência que tem cumplicidade jurídica, científica, cultural e institucional. Borrillo problematiza e exemplifica as doutrinas que veiculam a ideologia heterossexista, mostrando a mudança de papel do homossexual: de pecador para perverso e ameaçador da ordem 
sanitária. O último capítulo dedica-se a discutir as causas da homofobia, tratando-a como um fenômeno cuja compreensão demanda o entendimento de que essas práticas de preconceito não são somente individuais e tampouco meramente coletivas, e sim socialmente construídas, servindo para nutrir um sistema de exclusão e dominação. O autor trata de questões relativas à personalidade homofóbica e diferencia a definição de homofobia ao aprofundá-la e demonstrar que, ainda que a rejeição irracional aos homossexuais configurese como um importante componente da homofobia, considerar apenas esse aspecto é reduzir o significado desse fenômeno plural.

Borrillo classifica nossa sociedade como androcêntrica e afirma que, em grupos marcados pela dominação masculina, a homofobia organiza a vigilância de gênero. Para o autor, existe uma lógica binária de construção da identidade sexual em que a mulher está oposta ao homem, assim como o homossexual está ao heterossexual. A identidade sexual masculina é, então, construída de maneira a negar o feminino e rejeitar a homossexualidade. $O$ autor afirma que a homofobia é um elemento constitutivo da identidade masculina e que sexismo e homofobia são faces de um mesmo fenômeno social: "A homofobia - e, em particular, a masculina desempenha a função de 'policiamento da sexualidade' ao reprimir qualquer comportamento, gesto ou desejo que transborde as fronteiras impermeáveis dos sexos" (p. 90).

É apresentado neste capítulo o fantasma da desintegração psíquica, social e cultural, que consiste no temor do fim da continuidade genealógica e que, segundo o autor, leva ao incentivo à heterossexualidade, ao fortalecimento da diferença entre os sexos e, por consequência, à estigmatização da homossexualidade. $\mathrm{O}$ autor aponta esse temor como o condutor do entendimento de que os homossexuais estariam arriscando a sobrevivência da espécie e afirma que não se pode pensar essa possibilidade com seriedade, pontuando a existência de meios capazes de viabilizar a reprodução de forma alternativa ao coito heterossexual. Por fim, é discutido o processo de interiorização da homofobia, que faz com que gays e lésbicas, inseridos em uma sociedade que considera a heterossexualidade cultural e psicologicamente superior, direcionem ódio a si mesmos. Borrillo afirma que a dominação heterossexista, a escassez de referências culturais, o contexto de violência $e$ a perda da autoestima podem resultar no isolamento e na angústia do homossexual ou, ainda, na necessidade de manifestação pública da homossexualidade (coming-out) por uma questão afirmativa ou pela justificação social e inscrição em uma identidade sexual.

Na conclusão, o autor dedica-se a explorar os recursos para o enfrentamento da homofobia. Afirma que se deve dar maior importância à ação pedagógica, pois a repressão isolada não é capaz de dirimir a violência homofóbica. Borrillo, por fim, problematiza a criação de legislação para reprimir a homofobia e a pretensão de construção de uma identidade gay, lembrando a leitora de que a ideia de constituição de uma "personalidade homossexual" é ilusória e atende ao fim de reprimir. A obra contém muitos elementos do contexto histórico e social francês, porém, mesmo que se dedique a analisar o fenômeno nessa sociedade, não se restringe a isso. A homofobia não se limita à realidade francesa, mas, ao contrário, alcança toda sociedade que se organize em torno da heterossexualidade como natural aos sujeitos e que, portanto, marginalize outras formas de vivência da sexualidade.

Partindo do entendimento de que a homossexualidade representa uma manifestação do pluralismo sexual e é tão legítima quanto a heterossexualidade, o autor faz com que a leitora repense a importância da sexualidade como fator de definição da identidade de um indivíduo. Assim, Borrillo afina-se à Judith Butler' na medida em que indica que classificar e conceituar são ações totalitárias e reducionistas. Enquanto Butler conduz o entendimento de que pensar a existência de gêneros significa aceitar normas culturais regentes da interpretação dos corpos, Borrillo desconstrói a ideia de importância da sexualidade para definir um indivíduo e adverte que a violência homofóbica não depende de padrões de sexualidade para se expressar: "A homofobia manifesta sua hostilidade não só a gays e lésbicas, mas também a qualquer indivduo que não se adapte aos papéis, supostamente, determinados pelo sexo biológico" (p. 88).

Esta é uma leitura capaz de provocar e, minimamente, fazer a leitora problematizar convicções, podendo avaliar a possibilidade de ser manipulada pelo discurso de poder utilizado para manter uma hierarquia das sexualidades que classifica as não reprodutivas como inferiores e antinaturais. O livro de Borrillo deve ficar situado entre os clássicos que foram capazes de problematizar a questão da heterossexualidade como fator natural dos sujeitos. A leitura conduz - olhar sobre práticas e formas de preconceito muito sutis e faz perceber quão ampla é essa 
forma de violência que não somente afeta o indivíduo, mas corrói as bases democráticas ao promover a desigualdade, engessar gêneros e favorecer a hostilidade.

\section{Nota}

1 Judith BUTLER, 2003.

\section{Referências}

BUTLER, Judith P. Problemas de gênero: feminismo e subversão da identidade. Tradução de Renato Aguiar. Rio de Janeiro: Civilização Brasileira, 2003. 236 p.

Daniela Márcia Caixeta Costa Universidade de Brasília 